\title{
Management of Tagetes minuta under Different Sowing Methods and Plant Densities in Mid-Hill Condition of Himachal Pradesh (India)
}

\author{
Meenu Sood ${ }^{1}$, Nilay Kumar ${ }^{2 *}$ and Sunandani Chandel $^{3}$ \\ ${ }^{1}$ Department of Forest Products, College of Forestry, Dr. Y.S. Parmar UHF, \\ Nauni-173 230, Solan, Himachal Pradesh (India) \\ ${ }^{2}$ Department of Floriculture (Ornamental and Medicinal Plants), College of Horticulture \& \\ Forestry, Central Agricultural University, Pasighat -791 102, Arunachal Pradesh (India) \\ ${ }^{3}$ Department of Forest Products and Utilization, ASPEE College of Horticulture and Forestry, \\ NAU, Navsari-396 450, Gujarat (India)
}

*Corresponding author

A B S T R A C T

\begin{tabular}{l} 
K e y w o r d s \\
$\begin{array}{l}\text { Tagetes minuta, } \\
\text { broadcasting, plant } \\
\text { densities, seedling } \\
\text { planting, spacing }\end{array}$ \\
\hline Article Info \\
\hline $\begin{array}{l}\text { Accepted: } \\
\text { 10 April } 2020 \\
\text { Available Online: } \\
\text { 10 May } 2020\end{array}$ \\
\hline
\end{tabular}

Keywords

Tagetes minuta, broadcasting, plant densities, seedling planting, spacing

Article Info

10 April 2020

10 May 2020
A study was carried out for three years at Dr. Y. S. Parmar University of Horticulture and Forestry, Nauni, Solan to evaluate the effect of different sowing methods and plant densities on oil yield of Tagetes minuta. Different planting methods i.e. broadcasting and seedling planting with varying plant densities $\mathrm{S} 1(30 \times 15 \mathrm{~cm}), \mathrm{S} 2(30 \times 30 \mathrm{~cm}), \mathrm{S} 3(30 \times 45 \mathrm{~cm})$, $\mathrm{S} 4(45 \mathrm{x} 45 \mathrm{~cm})$ and $\mathrm{S} 5(45 \times 60 \mathrm{~cm})$ were evaluated under RBD Factorial design. The leaves biomass (pre-flowering stage), flower biomass and leaf + flower biomass (full bloom stage) yielded maximum oil at S3 (30 x $45 \mathrm{~cm})$ spacing. The leaf + flower biomass at full bloom stage yielded maximum BCR (Benefit Cost Ratio) in S3 (30 x 45cm).

\section{Introduction}

Tagetes minuta L. (synonymous $T$. glandulifera Schrank) commonly known as wild marigold is important source of "Tagetes oil". The oil, obtained from whole herbs or flowers, find extensive uses in food, flavour and cosmetic industry which makes it an economic industrial crop in Himachal Pradesh, Uttarakhand and Jammu \& Kashmir. In India, it is found in Western Himalayas between altitudes of 1000-2500 m (Singh et al., 2003; Prasad et al., 2003). T. minuta is an annual herb characterized by an erect stem of 
about 1-2 m height (Wang and Chen, 2006). The leaves are pinnately compound, stalked, opposite, slightly glossy, green in colour, 7-15 $\mathrm{cm}$ long, pinnately dissected into 4-6 pairs of pinnae. The leaflets are lanceolate in shape with finely serrate margins (Singh et al., 2003; Wang and Chen, 2006; Ofori et al., 2013). Flower heads are numerous, yellowish green, usually in flat topped cymes, involucres cylindrical, 8-14 $\mathrm{mm}$ high and 2$3 \mathrm{~mm}$ wide (Wang and Chen, 2006).

Flowers are arranged in solitary clustered panicled branches. Each head is surrounded by four or five involucres bracts fused together (Wanzala et al., 2012). The major components of the essential oil from aerial parts are (Z)- $\beta$-ocimene, dihydrotagetone, (E)- $\beta$-ocimene, (Z)- and (E)-tagetones, and (Z)- and (E)-tagetenones (Gupta and Vasudeva, 2012; Singh et al., 2015). In India, the freshly distilled $T$. minuta oil contained ocimene $54.97 \%$, and dihydrotegetone $32.58 \%$ as major constituents (Singh et al., 2003).

The essential oil obtained from this plant has been reported to have mosquitolarvicidal, anti-viral, hypotensive, spasmolytic, anti-inflammatory, antimicrobial, cytotoxic and anti-fungal properties (Shirazi et al., 2014). The quantity of oil yield is significantly affected by both environment and agronomy (Voirin et al., 1990).

A study was conducted to evaluate the effect of transplanting date on growth and yield of T. minuta (Kmar et al., 2012). The effect of irradiance stress and plant spacing on growth, biomass and quality of wild $T$. minuta was also studied (Kumar et al., 2014). Since $T$. minuta is an industrial crop of given area hence present study is conducted on the management of $T$. minuta under different sowing methods and plant densities.

\section{Materials and Methods}

The experiment was conducted out in the field of Department of Forest Products, College of Forestry, Dr. Y.S. Parmar University of Horticulture and Forestry, Nauni, Solan, Himachal Pradesh during the month of April to December for three years. The geographical location of the area having latitude $30^{\circ} 52^{\prime} \mathrm{N}$, longitude $77^{\circ} 11^{\prime} \mathrm{E}$ and altitude of $1250 \mathrm{~m}$.

The site falls under mid hill zone of Himachal Pradesh and characterized by traced and undulating topography. During the experimental period, the highest temperature was observed in May $\left(31.3^{\circ} \mathrm{C}\right)$ followed by June $\left(29.3^{\circ} \mathrm{C}\right)$ and September $\left(28.7^{\circ} \mathrm{C}\right)$ whereas, average minimum temperature were $2.6^{\circ} \mathrm{C}$ and $6.4^{\circ} \mathrm{C}$ recorded during January and December.

The area received maximum rainfall of 294.4 mm during July followed by August (102.2 $\mathrm{mm})$, June $(91.1 \mathrm{~mm})$ and September (41.6 $\mathrm{mm}$ ), while minimum rainfall was received during December $(6.8 \mathrm{~mm})$ and November month $(7.6 \mathrm{~mm})$ during the period of study.

Soil samples were taken randomly from the entire experimental area before sowing and were thoroughly mixed together, thus a composite representative sample from whole of the area was taken for chemical analysis to evaluate the fertility status of soil.

The experiment was laid out in Randomized Block Design (RBD Factorial) with two methods of planting i.e. broadcasting @ $6 \mathrm{~kg} / \mathrm{ha}$ and seedling planting with varying plant densities i.e. S1 $(30 \times 15 \mathrm{~cm}), \mathrm{S} 2(30 \mathrm{x}$ $30 \mathrm{~cm}), \mathrm{S} 3(30 \times 45 \mathrm{~cm}), \mathrm{S} 4(45 \times 45 \mathrm{~cm})$ and $\mathrm{S} 5(45 \times 60 \mathrm{~cm})$. The seeds were sown in the field during last fortnight of April and irrigation was done till the establishment of plants. 
After that the plants were left to grow under rain fed conditions and the field was kept free from weeds by doing manual weeding operations at 15 days interval. A basic dose of 120:60:30 $\mathrm{kg}$ NPK/ha was applied to supplement the nutritional demand of the crop. Observations were recorded at preflowering and flowering stage.

\section{At pre flowering stage}

\section{Leaf biomass}

Leaf biomass was recorded as mean from five sample plants after plucking the leaves.

\section{Essential oil content of leaf biomass}

The oil was extracted using Clevenger apparatus in the laboratory and oil per cent was calculated on v/w basis.

\section{Essential oil yield of leaf biomass}

The essential oil yield was estimated from the biomass of economic parts of the plant on the basis of per cent oil content from the biomass.

\section{At full bloom stage}

The data on leaf, essential oil content and essential oil yield of leaf biomass was recorded similarly as given above in the preflowering stage. The following additional observations were also recorded at flowering stage.

\section{Flower biomass}

Flower biomass was recorded as a mean from already selected five sample plants after plucking the flowers.

\section{Total biomass}

It was the sum total of mean of each leaf and flower biomass of already selected five plants.

\section{Essential oil content of flower}

The oil was extracted using Clevenger apparatus in the laboratory and oil per cent was calculated on v/w basis.

\section{Essential oil yield of flower}

The essential oil yield was estimated from the biomass of flower on the basis of per cent oil content from the biomass.

\section{Cost benefit ratio}

T. minuta L. is an important crop whose flower and leaf oil are used for medicinal purposes. Because of the importance, it is essential to find out the cost of cultivation of this crop. The crop was raised under different treatments and cost benefit ratio was calculated on the basis of cost of cultivation and returns on per hectare basis.

\section{Statistical analysis}

The data recorded was subjected to statistical analysis under Randomized Block Design and Randomized Block Design Factorial. Analysis of variance was worked out and critical difference at 5 per cent level of significance was calculated.

\section{Results and Discussion}

The data on leaf biomass per plant and leaf biomass per hectare of $T$. minuta at preflowering stage under different sowing methods i.e. Broadcasting and seedling planting with varying plant densities $\mathrm{S} 1(30 \mathrm{x}$ $15 \mathrm{~cm}), \mathrm{S} 2(30 \times 30 \mathrm{~cm}), \mathrm{S} 3(30 \times 45 \mathrm{~cm})$, $\mathrm{S} 4(45 \times 45 \mathrm{~cm})$ and $\mathrm{S} 5(45 \times 60 \mathrm{~cm})$ is represented in Table $1 \& 2$. In seedling planting method, the pooled data of spacing S5 $(45 \times 60 \mathrm{~cm})$ yield was observed $(72.11 \mathrm{~g})$ maximum in leaf biomass per plant at preflowering stage as compared to full bloom 
stage $(70.87 \mathrm{~g})$ in the same spacing. Moreover, the leaf biomass per hectare yield was recorded maximum (50.19 q) in $\mathrm{S} 3(30 \mathrm{x}$ $45 \mathrm{~cm}$ ) spacing at pre-flowering stage as compare to full bloom stage $(45.61 \mathrm{q})$ in the same spacing. In broadcasting method, the leaf biomass per plant was recorded $18.43 \mathrm{~g}$ at pre-flowering stage as compared to full bloom stage i.e. $14.05 \mathrm{~g}$ and the same trend was also recorded in leaf biomass per hectare at pre- flowering stage i.e. $43.17 \mathrm{q}$ as compared to full bloom stage i.e. 32.24 q. The results revealed that the large spacing increase more plant growth as compare to less spacing whereas large spacing reduces the number of plant per bed and that lead to reduce the overall yield per hectare. Such studies are also revealed by Meena et al., 2015; Kumar et al., 2019; Lakshmi et al., 2014 in African marigold.

Table.1 Effect of sowing methods and plant densities on leaf biomass per plant and leaf biomass yield at pre flowering stage of Tagetes minuta

\begin{tabular}{|c|c|c|c|c|c|c|c|c|}
\hline \multirow{2}{*}{$\begin{array}{l}\text { Method of } \\
\text { Sowing }\end{array}$} & \multicolumn{4}{|c|}{ Leaf biomass/plant (g) } & \multicolumn{4}{|c|}{ Leaf Biomass/ha (q) } \\
\hline & $1^{\text {st }}$ Year & $\begin{array}{l}2^{\text {nd }} \\
\text { Year }\end{array}$ & $3^{\text {rd }}$ Year & $\begin{array}{c}\text { Pooled } \\
\text { mean }\end{array}$ & $1^{\text {st }}$ Year & $\begin{array}{l}2^{\text {nd }} \\
\text { Year }\end{array}$ & $\begin{array}{l}3^{\text {rd }} \\
\text { Year }\end{array}$ & $\begin{array}{c}\text { Pooled } \\
\text { mean }\end{array}$ \\
\hline Broadcasting & 18.43 & 17.42 & 19.44 & 18.43 & 42.78 & 44.92 & 41.83 & 43.17 \\
\hline \multicolumn{9}{|c|}{ Transplanted seedlings } \\
\hline S1 $(30 \times 15 \mathrm{~cm})$ & 21.23 & 20.43 & 24.52 & 22.06 & 47.18 & 44.53 & 46.19 & 45.97 \\
\hline $\mathrm{S} 2(30 \times 30 \mathrm{~cm})$ & 37.78 & 34.65 & 36.88 & 36.43 & 41.89 & 43.02 & 42.45 & 42.45 \\
\hline $\mathrm{S3}(30 \times 45 \mathrm{~cm})$ & 60.57 & 57.41 & 61.74 & 59.91 & 50.47 & 48.47 & 51.64 & 50.19 \\
\hline S4 $(45 \times 45 \mathrm{~cm})$ & 68.47 & 69.32 & 66.05 & 67.95 & 38.04 & 42.73 & 42.58 & 41.12 \\
\hline $\mathrm{S5}(45 \times 60 \mathrm{~cm})$ & 72.40 & 73.44 & 70.51 & 72.11 & 26.81 & 30.32 & 31.46 & 29.53 \\
\hline CD at $5 \%$ & 4.69 & 4.16 & 4.62 & 4.14 & 2.99 & 2.72 & 2.84 & 2.12 \\
\hline CV at $5 \%$ & 19.62 & 14.27 & 5.47 & 13.58 & 7.26 & 8.72 & 7.92 & 7.92 \\
\hline
\end{tabular}

Table.2 Effect of sowing methods and plant densities on leaf biomass per plant and leaf biomass yield at full bloom stage of Tagetes minuta

\begin{tabular}{|l|c|c|c|c|c|c|c|c|}
\hline \multirow{2}{*}{$\begin{array}{c}\text { Method of } \\
\text { Sowing }\end{array}$} & \multicolumn{5}{|c|}{ Leaf biomass /plant (g) } & \multicolumn{4}{c|}{ Leaf Biomass/ha (q) } \\
\cline { 2 - 10 } & $1^{\text {st }}$ Year & $2^{\text {nd }}$ Year & $3^{\text {rd }}$ Year & $\begin{array}{c}\text { Pooled } \\
\text { mean }\end{array}$ & $1^{\text {st }}$ Year & $2^{\text {nd }}$ Year & $3^{\text {rd }}$ Year & $\begin{array}{c}\text { Pooled } \\
\text { mean }\end{array}$ \\
\hline Broadcasting & 14.45 & 12.48 & 15.22 & 14.05 & 33.79 & 30.78 & 32.16 & 32.24 \\
\hline Transplanted seedlings & & & & & & & \\
\hline S1 (30x15cm) & 17.10 & 20.36 & 18.25 & 18.57 & 38.00 & 36.96 & 40.12 & 38.36 \\
\hline S2 (30x30cm) & 34.23 & 37.71 & 36.55 & 36.16 & 39.26 & 34.52 & 36.55 & 36.78 \\
\hline S3 (30x45cm) & 56.87 & 53.73 & 59.06 & 56.54 & 45.64 & 42.57 & 48.62 & 45.61 \\
\hline S4 (45x45 cm) & 64.30 & 63.32 & 69.46 & 65.69 & 35.72 & 32.67 & 37.14 & 35.18 \\
\hline S5 (45x60 cm) & 68.48 & 72.74 & 71.39 & 70.87 & 25.33 & 24.86 & 28.81 & 26.33 \\
\hline CD at 5\% & 2.27 & 2.96 & 2.84 & 2.49 & 3.12 & 3.26 & 3.16 & 3.62 \\
\hline CV at 5\% & 12.52 & 10.62 & 9.82 & 10.45 & 14.26 & 12.91 & 11.52 & 12.78 \\
\hline
\end{tabular}


Table.3 Effect of sowing methods and plant densities on flower biomass per plant and flower biomass yield at full bloom stage of Tagetes minuta

\begin{tabular}{|l|c|c|c|c|c|c|c|c|c|}
\hline \multirow{2}{*}{$\begin{array}{c}\text { Method of } \\
\text { Sowing }\end{array}$} & \multicolumn{5}{|c|}{ flower biomass/plant (g) } & \multicolumn{4}{c|}{ flower biomass/ha (q) } \\
\cline { 2 - 10 } & $1^{\text {st }}$ Year & $2^{\text {nd }}$ Year & $3^{\text {rd }}$ Year & $\begin{array}{c}\text { Pooled } \\
\text { mean }\end{array}$ & $1^{\text {st }}$ Year & $2^{\text {nd }}$ Year & $3^{\text {rd }}$ Year & $\begin{array}{c}\text { Pooled } \\
\text { mean }\end{array}$ \\
\hline Broadcasting & 15.87 & 13.37 & 16.44 & 15.23 & 32.86 & 29.64 & 32.33 & 31.61 \\
\hline Transplanted seedlings & \multicolumn{3}{|c|}{} & & & & & & \\
\hline S1 (30x15cm) & 16.60 & 18.21 & 21.54 & 18.85 & 36.89 & 32.89 & 39.26 & 36.34 \\
\hline S2 (30x30cm) & 33.80 & 32.38 & 36.27 & 34.08 & 37.56 & 36.77 & 39.67 & 38.00 \\
\hline S3 (30x45cm) & 50.00 & 43.89 & 52.28 & 48.72 & 41.67 & 43.62 & 44.08 & 43.12 \\
\hline S4 (45x45 cm) & 59.87 & 61.77 & 57.39 & 59.68 & 33.26 & 34.35 & 36.27 & 34.62 \\
\hline S5 (45x60 cm) & 67.93 & 69.51 & 69.19 & 68.87 & 25.16 & 28.94 & 28.53 & 27.54 \\
\hline CD at 5\% & 2.52 & 2.41 & 2.64 & 2.52 & 2.06 & 2.21 & 2.14 & 2.17 \\
\hline CV at 5\% & 8.22 & 9.37 & 8.49 & 8.69 & 9.21 & 8.23 & 8.31 & 6.71 \\
\hline
\end{tabular}

Table.4 Effect of sowing methods and plant densities on oil yield from leaf biomass $(\mathrm{kg} / \mathrm{ha})$ at pre flowering and at full bloom stage of Tagetes minuta

\begin{tabular}{|c|c|c|c|c|c|c|c|c|}
\hline \multirow[t]{2}{*}{ Method of Sowing } & \multicolumn{4}{|c|}{$\begin{array}{l}\text { Oil yield from leaf biomass at Pre- } \\
\text { flowering stage }(\mathrm{kg} / \mathrm{ha})\end{array}$} & \multicolumn{4}{|c|}{$\begin{array}{c}\text { Oil yield from leaf biomass at full bloom } \\
\text { stage }(\mathrm{kg} / \mathrm{ha})\end{array}$} \\
\hline & $1^{\text {st }}$ Year & $2^{\text {nd }}$ Year & $3^{\text {rd }}$ Year & $\begin{array}{c}\text { Pooled } \\
\text { mean }\end{array}$ & $1^{\text {st }}$ Year & $2^{\text {nd }}$ Year & $3^{\text {rd }}$ Year & $\begin{array}{c}\text { Pooled } \\
\text { mean }\end{array}$ \\
\hline Broadcasting & 14.11 & 14.82 & 13.80 & 14.24 & 9.70 & 8.42 & 9.23 & 9.14 \\
\hline \multicolumn{9}{|c|}{ Transplanted seedlings } \\
\hline S1 $(30 \times 15 \mathrm{~cm})$ & 15.57 & 14.69 & 15.24 & 15.17 & 11.40 & 10.83 & 10.47 & 10.9 \\
\hline S2 $(30 \times 30 \mathrm{~cm})$ & 13.82 & 14.20 & 14.01 & 15.01 & 11.42 & 12.03 & 12.48 & 11.98 \\
\hline $\mathrm{S3}(30 \times 45 \mathrm{~cm})$ & 16.66 & 15.10 & 17.04 & 16.26 & 13.69 & 12.78 & 13.72 & 13.40 \\
\hline $\mathrm{S} 4(45 \times 45 \mathrm{~cm})$ & 12.55 & 14.11 & 14.05 & 13.57 & 10.71 & 9.48 & 11.79 & 10.66 \\
\hline S5 $(45 \times 60 \mathrm{~cm})$ & 8.85 & 10.01 & 10.38 & 9.75 & 07.60 & 08.61 & 08.49 & 8.23 \\
\hline CD at $5 \%$ & 5.14 & 5.48 & 4.81 & 5.14 & 1.51 & 04.50 & 03.56 & 04.03 \\
\hline CV at $5 \%$ & 18.12 & 12.91 & 10.46 & 13.83 & 5.62 & 10.56 & 8.34 & 11.24 \\
\hline
\end{tabular}

Table.5 Effect of sowing methods and plant densities on oil yield from flower biomass (kg/ha) and leaf biomass + flower biomass at full bloom stage of Tagetes minuta

\begin{tabular}{|c|c|c|c|c|c|c|c|c|}
\hline \multirow[t]{2}{*}{ Method of Sowing } & \multicolumn{4}{|c|}{$\begin{array}{c}\text { Oil yield from flower biomass at full } \\
\text { bloom stage }(\mathrm{kg} / \mathrm{ha})\end{array}$} & \multicolumn{4}{|c|}{$\begin{array}{l}\text { Oil yield from leaf }+ \text { flower biomass at full } \\
\text { bloom stage }(\mathrm{kg} / \mathrm{ha})\end{array}$} \\
\hline & $1^{\text {st }}$ Year & $2^{\text {nd }}$ Year & $3^{\text {rd }}$ Year & $\begin{array}{c}\text { Pooled } \\
\text { mean }\end{array}$ & $1^{\text {st }}$ Year & $2^{\text {nd }} Y e a r$ & $3^{\text {rd }}$ Year & $\begin{array}{c}\text { Pooled } \\
\text { mean }\end{array}$ \\
\hline Broadcasting & 14.78 & 16.88 & 13.93 & 15.19 & 24.48 & 25.30 & 23.16 & 24.11 \\
\hline \multicolumn{9}{|c|}{ Transplanted seedlings } \\
\hline S1 $(30 \times 15 \mathrm{~cm})$ & 18.07 & 17.45 & 18.23 & 17.92 & 29.47 & 28.28 & 28.70 & 28.81 \\
\hline S2 $(30 \times 30 \mathrm{~cm})$ & 18.40 & 19.04 & 18.63 & 18.69 & 29.82 & 31.07 & 31.11 & 30.67 \\
\hline S3 $(30 \times 45 \mathrm{~cm})$ & 20.42 & 19.67 & 20.38 & 20.16 & 34.11 & 32.45 & 34.10 & 33.55 \\
\hline $\mathrm{S} 4(45 \times 45 \mathrm{~cm})$ & 16.30 & 18.29 & 1652 & 17.04 & 27.01 & 27.77 & 28.31 & 27.70 \\
\hline S5 $(45 \times 60 \mathrm{~cm})$ & 12.33 & 13.06 & 13.95 & 13.11 & 19.93 & 21.67 & 22.44 & 21.35 \\
\hline CD at $5 \%$ & 1.51 & 1.63 & 1.82 & 1.57 & 1.87 & 1.92 & 1.81 & 1.91 \\
\hline $\mathrm{CV}$ at $5 \%$ & 5.72 & 6.78 & 6.82 & 7.48 & 6.92 & 5.38 & 6.71 & 7.52 \\
\hline
\end{tabular}


Table.6 Effect of sowing methods and plant densities on gross income, net income and $\mathrm{B}$ : $\mathrm{C}$ ratio

\begin{tabular}{|l|c|c|c|c|}
\hline \multicolumn{1}{|c}{$\begin{array}{c}\text { Method of } \\
\text { Sowing }\end{array}$} & $\begin{array}{c}\text { Oil yield from leaf + flower } \\
\text { biomass at full bloom stage } \\
\text { (kg/ha) }\end{array}$ & Gross income & Net income & $\begin{array}{c}\text { B:C } \\
\text { Ratio }\end{array}$ \\
\hline Broadcasting & 24.11 & 41,770 & $10,337.5$ & 2.62 \\
\hline Transplanted seedlings & & & & \\
\hline S1 (30X15 cm) & 28.81 & $1,06,670$ & $64,237.5$ & 3.14 \\
\hline S2 (30X30 cm) & 30.67 & $1,11.090$ & $74,603.5$ & 3.97 \\
\hline S3 (30X45 cm) & 33.55 & $1,19,180$ & $79,657.5$ & 4.32 \\
\hline S4 (45X45 cm) & 27.70 & 49,650 & $12,217.5$ & 3.03 \\
\hline S5 (45X60 cm) & 21.35 & 36,930 & 9,816 & 2.21 \\
\hline CD at 5\% & 1.91 & 968.03 & 1254.23 & 0.06 \\
\hline CV at 5\% & 7.52 & 24.02 & 36.12 & 0.19 \\
\hline
\end{tabular}

The pooled data shown in Table 3 of seedling transplanting method depicts that the maximum flower biomass per plant $(68.87 \mathrm{~g})$ was observed in $\mathrm{S} 5(45 \times 60 \mathrm{~cm})$ spacing whereas the maximum flower biomass per hectare (43.12 q) was recorded in S3 (30 x $45 \mathrm{~cm})$ spacing. Such results occur due to greater number of plants per bed in S3 $(30 \mathrm{x}$ $45 \mathrm{~cm})$ as compared to $\mathrm{S} 5(45 \times 60 \mathrm{~cm})$ spacing.

Simultaneously, greater number of plants per bed leads to higher growth and yield of flower biomass per hectare in $\mathrm{S} 3(30 \times 45 \mathrm{~cm})$ spacing. Similar results are also studied by Karuppaiah and Krishna 2005 in Tagetes erecta. Whereas, in broadcasting method, the flower biomass per plant was recorded i.e. $15.23 \mathrm{~g}$ when compare to flower biomass per hectare i.e. $31.61 \mathrm{q}$ at full bloom stage.

The pooled data shown in Table $4 \& 5$ of seedling planting method revealed that the maximum oil yield from leaf biomass at S3 $(30 \mathrm{x} 45 \mathrm{~cm})$ spacing was observed 16.26 $\mathrm{kg} / \mathrm{ha}$ at pre flowering as compared to maximum oil yield from leaf biomass at full bloom stage i.e. $13.40 \mathrm{~kg} / \mathrm{ha}$ in the same spacing. Whereas, maximum oil yield from flower biomass at full bloom stage was observed $20.16 \mathrm{~kg} / \mathrm{ha}$ as compared to maximum oil yield from leaf + flower biomass at full bloom stage was observed $33.55 \mathrm{~kg} / \mathrm{ha}$. The results show that the higher biomass yield at S3 $(30 \times 45 \mathrm{~cm})$ spacing produces higher essential oil yield. Similar results were reported by Kumar et al., 2014 in T. minuta. In broadcasting, oil yield from leaf biomass was observed $14.24 \mathrm{~kg} / \mathrm{ha}$ as compared to oil yield from leaf biomass at full bloom stage i.e. $9.14 \mathrm{~kg} / \mathrm{ha}$ at pre flowering and flowering stage.

Further, during full bloom stage, oil yield from flower biomass was recorded 15.19 $\mathrm{kg} / \mathrm{ha}$ oil as compare to oil yield from leaf + flower biomass i.e. $24.11 \mathrm{~kg} / \mathrm{ha}$. Seedling planting method gives higher biomass and oil yield as compared to broadcasting as nursery sowing makes the plant better to adopt in the environment and reduce the mortality rate.

Table 6 revealed that maximum B:C ratio was observed 4.32 in $\mathrm{S} 3(30 \times 45 \mathrm{~cm})$ whereas minimum was recorded 2.21 in S5 (45 $\mathrm{x}$ $60 \mathrm{~cm})$ as compared to broadcasting i.e. 2.62 . The results depicted higher B:C ratio in S3 $(30 \times 45 \mathrm{~cm})$ spacing due to high yield and low cost of cultivation as compared to others. The type of sowing methods i.e. Broadcasting and transplanting seedlings under different plant densities $\mathrm{S} 1(30 \mathrm{x} 15 \mathrm{~cm}), \mathrm{S} 2(30 \mathrm{x}$ 
$30 \mathrm{~cm}), \mathrm{S} 3(30 \times 45 \mathrm{~cm}), \mathrm{S} 4(45 \times 45 \mathrm{~cm})$ and $\mathrm{S} 5(45 \times 60 \mathrm{~cm})$ significantly affected the growth and yield of oil in Tagetes minuta. The seedlings planted at $\mathrm{S} 1(30 \times 45 \mathrm{~cm})$ spacing yields maximum leaf, flower, leaf + flower biomass and essential oil yield. The comparative analysis of different sowing methods revealed that the transplanted seedlings at spacing $(30 \mathrm{x} 45 \mathrm{~cm})$ gives $14.18 \%$ increased oil yield from leaves than broadcasting method at pre-flowering stage whereas at full bloom stage, there is an increase of $39.15 \%$ oil yield from leaf + flower biomass than broadcasting method. Thus, seedling planting at spacing (30 x $45 \mathrm{~cm})$ is recommended for obtaining maximum benefits as due to high yield and low cultivation cost than the others method of sowing and spacing.

\section{Acknowledgement}

We would like to thank AICRP on Medicinal and Aromatic Plants, Boriavi, Anand, Gujarat for providing financial assistance to complete the research work on time.

\section{References}

Gupta, P. and Vasudeva, N. 2012. Marigold: A potential ornamental plant drug. Hamdard Medical, 55: 45-59.

Karuppaiah, P. and Krishna, G. 2005. Response of spacings and nitrogen levels on growth flowering and yield characters of French marigold (Tagetes patula L.). Journal of Ornamental Horticulture, 8(2): 96-99.

Kumar, R., Ramesh K., Pathania, V. and Singh, B. 2012. Effect of Transplanting Date on Growth, Yield and Oil Quality of Tagetes minuta L. in Mid Hill of North -Western Himalaya. Journal of Essential Oil Bearing Plants, 15(3): 405-414.

Kumar, R., Sharma, S., Ramesh, K., Pathania,
V. and Prasad, R. 2014. Irradiance stress and plant spacing effect on growth, biomass and quality of wild marigold (Tagetes minuta L.) - an industrial crop in western Himalaya. Journal of Essential Oil Research, 26(5): 348-358.

Kumar, V., Singh, R.S., Pal, M., Ojha, M.D., Verma, R.B., Verma, R.K., Kumar, N. and Singh, A.P. 2019. Growth and flower yield attributes of African marigold (Tagetes erecta L.) as influenced by planting geometry and varieties. Journal of Pharmacognosy and Phytochemistry, 8(1): 819-822.

Lakshmi, Pandey, R.K., Dogra, S., Laishram, N., Bhat, D., Singh, A. and Jamwal, S. 2014. Studies on effects of planting dates and spacing in African marigold (Tagetes erecta L.). Progressive Horticulture, 46(1): 149-152.

Meena, Y., Siroh, H.S., Tomar, B.S. and Kumar, S. 2015. Effect of planting time, spacing and pinching on growth and seed yield traits in African marigold (Tagetes erecta) cv. Pusa NarangI Gainda. Indian Journal of Agriculture Sciences, 85(6): 797-801.

Ofori DA, Anjarwalla P, Mwaura L, Jamnadass R, Stevenson PC and Smith P. 2013. Pesticidal plant leaflet Tagetes minuta L. The University of Greenwich. Kew Royal Botanical Garden, UK.

Prasad, A., Krishna, A., Garg, S.N., Bhasney, S. and Singh, D.V. 2003. Growth yield and cation accumulation in Tagetes (Marigold) species under sodic soils. Journal of Medicinal and Aromatic Plants, 25: 408-413.

Shirazi, M.T., Gholami, H., Kavoosi, G., Rowshan, V. and Tafsiry, A. 2014. Chemical composition, antioxidant, antimicrobial and cytotoxic activities of Tagetes minuta and Ocimum basilicum essential oils. Food Science and Nutrition, 2(2): 146-55. 
Singh, P., Krishna, A., Kumar, V., Krishna, S., Singh, K., Gupta, M. and Singh, S. 2015. Chemistry and biology of industrial crop Tagetes species: A review. Journal of Essential Oil Research, 28: 1-14.

Singh, V., Singh, B. and Kaul, V.K. 2003. Domestication of wild marigold (Tagetes minuta L.) as a potential economic crop in western Himalaya and North Indian plains. Economic Botany, 57: 535-544.

Singh, Y., Verma, P. and Verma, J.P. 2008. Effect of NPK, spacing and $\mathrm{MH}$ on flower yield of African marigold (Tagetes erecta L.) CV. PNG. Annals of
Horticulture, 1(1): 27-31.

Voirin, B., Brun, N. and Bayat, C. 1990. Effects of day length on the monoterpene composition of leaves of Mentha $\times$ piperata. Phytochemistry, 29: 749-755.

Wang, C. and Chen, C. 2006. Tagetes minuta L. (Asteraceae), a newly naturalized plant in Taiwan. Taiwania, 51(1): 32-35.

Wanzala, W., Takken, W., Pala, A.O., Mukabana, R.W. and Hassanali, A. 2012. Ethnoknowledge of Bukusu community on livestock tick prevention and control in Bungoma district, western Kenya. Journal of Ethnopharmacology, 140(2): 298-324.

\section{How to cite this article:}

Meenu Sood, Nilay Kumar and Sunandani Chandel. 2020. Management of Tagetes minuta under Different Sowing Methods and Plant Densities in Mid-Hill Condition of Himachal Pradesh (India). Int.J.Curr.Microbiol.App.Sci. 9(05): 1516-1523.

doi: https://doi.org/10.20546/ijcmas.2020.905.172 